\title{
Survey on Wild Rodents for Endoparasites in Iwate Prefecture, Japan
}

\author{
Megumi ITO $^{1)}$ and Tadashi ITAGAKI ${ }^{1,2)}$ \\ ${ }^{1)}$ Laboratory of Parasitology, Department of Veterinary Medicine, Faculty of Agriculture, Iwate University, Morioka 020-8550, and \\ ${ }^{2)}$ The United Graduate School of Veterinary Sciences, Gifu University, 1-1 Yanagido, Gifu 501-1193, Japan
}

(Received 27 February 2003/Accepted 7 July 2003)

ABSTRACT. Wild rodents (58 Apodemus speciosus, 29 A. argenteus and 7 Microtus montebelli) were surveyed for endoparasites in Iwate Prefecture, Japan, from October to December 1995 and from April to October 1996. Two trematodes (Echinostoma macrorchis, Plagiorchis muris), 4 or more cestodes ( Hymenolepis diminuta, Raillietina coreensis, Cladothyridium spp., Cysticercus fasciolaris), 12 nematodes (Carolinensis minutus, Eucoleus sp., Heligmosomoides kurilensis, H. protobullosus, H. speciosus, Heterakis spumosa, Rhabditis (Pelodera) orbitalis, Rictularia cristata, Syphacia emileromani, S. frederici, S. montana, Trichuris sp.) and 3 protozoans (Giardia sp., Trichomonas sp., Trypanosoma sp.) were identified. The two species of Apodemus were similar to each other, but they were extremely different from $M$. montebelli in parasite fauna.

KEY WORDS: endoparasite, Japan, wild rodent.

J. Vet. Med. Sci. 65(10): 1151-1153, 2003

Wild rodents act as definitive and/or intermediate hosts of many endoparasites including helminthes with zoonotic potential such as Echinococcus multilocularis. Therefore, they have been investigated for parasites, especially for helminths, in some districts of Japan [4-6, 13, 21, 22]. Recently, the first human case of babesiosis in Japan has been reported and showed that the etiological agent was an indigenous Japanese parasite which might be a geographical variant of Babesia microti involved in rodent infections [16]. This report suggested the importance of parasitic survey on wild rodents from the viewpoint of public health. In the present study, we captured wild rodents in the central area of Iwate prefecture and examined endoparasites including protozoans.

From October to December 1995 and from April to October 1996, rodents were caught using alive-traps in nine sites of forest in Morioka, Shizukuishi, Takizawa and Tamayama. The rodents captured were identified to species level according to Tanaka [18]. The animals were euthanitized. Then, blood smears were prepared by routine technique. The visceral organs and the tissue around eyes were removed from each animal and examined for helminths under a stereoscopicmicroscope. For observation of protozoan parasites, stamped tissues stained with hematoxylin were used. In addition, the muscle of face and legs was examined for the larvae of Trichinella species by the trypsin digestion method. The helminths recovered were fixed in $70 \%$ ethanol or $10 \%$ formalin. For identification of species, flukes and cestodes were stained with hematoxylin-carmine and nematodes were cleared in phenol-lactic acid.

Ninety-four rodents captured were 58 Apodemus speciosus, 29 A. argenteus and 7 Microtus montebelli. The 2 species of Apodemus were caught in all the 9 collecting sites. Further, A. speciosus was collected in each month except for June and July. The results of survey on parasite fauna are presented in Table 1. Two trematode, 4 or more cestode, 12 nematode and 3 protozoan species were identified. The two species of Apodemus were similar to each other in parasite fauna, but they were extremely different from $M$. montebelli. The prevalence of the 2 trematode species was very low, and only 8 immature flukes of Echinostoma macrorchis and a single adult of Plagiorchis muris were detected from the 2 animals of $A$. speciosus respectively. In contrast, Heligmosomoides speciosus and Trichomonas sp., and Carolinensis minutus and Giardia sp. were the most dominant in the 2 species of Apodemus and M. montebelli, respectively. Trypanosoma sp. in A. speciosus showed the high infection rate of $40 \%$ in August than in the other months. Bladder worms with a diameter of 1.5-2 mm were found in the liver of $A$. speciosus and M. montebelli. The protoscolex was invaginated in the body and had a rosterum with large and small hooks arranged alternately. The size of both hooks was $2 \mu \mathrm{m}$ and $14 \mu \mathrm{m}$, and $17 \mu \mathrm{m}$ and $12 \mu \mathrm{m}$ in the worms from A. speciosus and M. montebelli, respectively. From these morphological findings, the worms were considered to be cladothyridia of the genus Cladotaenia according to Abulodze [1]. The cladothyridia from A. speciosus were very akin to those from A. speciosus previously reported in Hokkaido, Japan [13, 22]. In the present study, female nematodes with a measurement of $\leq 34.95 \mathrm{~mm} \times 0.14$ $\mathrm{mm}$ were obtained from the gastric mucosa of 5 A. speciosus. The vulva was located $10.58 \mathrm{~mm}$ distant from the head end, and the intrauterus eggs measured $61 \times 26 \mu \mathrm{m}$ on average. From these findings the nematodes seemed to belong to the genus Eucoleus according to Moravec [15], but we could not identified them into species level since no male worms were obtained. Eucoleus sp. was reported from $A$. speciosus in some area of Japan [5,6]. Trichuris muris has been reported sporadically from wild rodents of 18 genera including Apodemus [7, 8, 10, 11, 14, 20, 23]. Further, T. avicolae has been described recently as a new species in rodents of the family Arvicolidae, and can be clearly differentiated from $T$. muris in vaginal length and egg size [9]. In the present study, 2 female whipworms were recovered 
Table 1. Endoparasites detected from wild rodents in Iwate Prefecture

\begin{tabular}{|c|c|c|c|}
\hline \multirow[t]{2}{*}{ Parasite species } & \multicolumn{3}{|c|}{ Incidence $(\%)$} \\
\hline & A. speciosus & A. argenteus & M. montebelli \\
\hline \multicolumn{4}{|l|}{ (Trematoda) } \\
\hline Echinostoma macrorchis & 1.7 & 0 & 0 \\
\hline Plagiorchis muris & 1.7 & 0 & 0 \\
\hline \multicolumn{4}{|l|}{ (Cestoda) } \\
\hline Hymenolepis diminuta & 18.9 & 3.4 & 0 \\
\hline Raillietina coreensis & 53.4 & 44.8 & 0 \\
\hline Cladothyridium spp. & 13.8 & 0 & 28.6 \\
\hline Cysticercus fasciolaris & 3.4 & 3.4 & 0 \\
\hline \multicolumn{4}{|l|}{ (Nematoda) } \\
\hline Carolinensis minutus & 0 & 0 & 100 \\
\hline Eucoleus sp. & 8.6 & 0 & 0 \\
\hline Heligmosomoides kurilensis & 46.6 & 3.4 & 0 \\
\hline Heligmosomoides protobullosus & 0 & 0 & 28.6 \\
\hline Heligmosomoides speciosus & 100 & 96.6 & 0 \\
\hline Heterakis spuтosa & 51.7 & 3.4 & 0 \\
\hline Phabditis (Pelodera) orbitalis & 0 & 0 & 28.6 \\
\hline Rictularia cristata & 32.8 & 3.4 & 0 \\
\hline Syphacia emileromani & 5.2 & 27.6 & 0 \\
\hline Syphacia frederici & 3.4 & 0 & 0 \\
\hline Syphacia montana & 0 & 0 & 14.3 \\
\hline Trichuris sp. & 0 & 0 & 14.3 \\
\hline \multicolumn{4}{|l|}{ (Protozoa) } \\
\hline Giardia sp. & 67.2 & 13.8 & 100 \\
\hline Trichomonas sp. & 87.9 & 69 & 0 \\
\hline Trypanosoma sp. & 13.8 & 0 & 0 \\
\hline
\end{tabular}

from the cecum of a single $M$. montebelli. Although we could not measure the length of vagina, the eggs collected from the uterus were $67 \times 33 \mu \mathrm{m}$ in average size, closely resembling those of T. muris. Giardia duodenalis (syn. G. intestinalis; G. lamblia) and G. muris are morphologically recognized as valid species [19]. These 2 species are differed from each other in the body size and shape of median bodies of the trophozoite. Since Giardia trophozoites found in this study were $9-12 \times 6-8 \mu \mathrm{m}$ in size and had small round median bodies, they were likely to be G. muris. A case of Trypanosoma sp. infection has been described in $A$. speciosus in Japan [2]. In the present study, the trypomastigotes obtained from blood of $A$. speciosus were $21 \mu \mathrm{m}$ in average size that was identical to that of Trypanosoma sp. in the previous record [2].

From the results obtained in the present study, it is suggested that the endoparasites detected showed some host specificity. Further, helminth parasites from each rodent species were mostly identical to those found in the previous surveys [4-6, 13, 21, 22]. Plagiorchis muris and Hymenolepis diminuta are known as zoonotic pathogens. However, public health importance of these 2 helminths has been nearly ignored, because human infections caused by them are extremely rare [3, 23]. Hydatid cysts of E. multilocularis were reported in A. argenteus in Hokkaido [22]. However, the cysts were not detected in the present study as well as in the previous studies carried out in the Honshu district $[4,6,12]$. On the other hand, there are few reports on protozoan parasites from wild rodents [2, 17]. Moreover, all the reports delt with blood protozoans such as Babesia sp. [17] and Trypanosoma sp. [2]. Therefore, Giardia sp. (probably G. muris) will be first recorded in this report from A. speciosus, A. argenteus and M. montebelli. Thus, further investigation will be required to identify the protozoan parasites in wild rodents.

This study was supported in part by a Grant-in-Aid for Scientific Research (The 21st Century Center-of-Excellence Program) from the Ministry of Education, Culture, Sports, Science and Technology of Japan (E-1).

\section{REFERENCES}

1. Abulodze, K. I. 1964. [Essentials of cestodology, 4, Moscow], Acad. Sci., USSR (in Russian).

2. Aita, J. and Saito, S. 1984. Jpn. J. Parasitol. 32 (Suppl.): 73-74 (in Japanese).

3. Asada, J-I., Otagaki, H., Morita, O., Takeuchi, T., Sakai, Y., Konishi, T. and Okahashi, K. 1962. Jpn. J. Parasitol. 11: 512516.

4. Asakawa, M. and Tomonari, T. 1988. Bull. Biogeogr. Soc. Jpn. 43: 19-23 (in Japanese with English summary).

5. Asakawa, M., Tanaka, N., Aoki, Y., Hasegawa, H., Fukumoto, SI. and Ohbayashi, M. 1992. Jpn. J. Parasitol. 41: 527-530.

6. Asakawa, M., Tanaka, N., Aoki, Y., Fushiki, H., Kurata, D., Fukumoto, SI. and Ohbayashi, M. 1992. J. Rakuno Gakuen Univ. 17: 75-79 (in Japanese with English summary).

7. Behnke, J. M., Lewis, J. W., Zain, S. N. and Gilbert, F. S. 1999. J. Helminthol. 73: 31-44.

8. Born, J. C., Lochmiller, R. L., Boggs, J. F. and Leslie, D. M. 1993. Southwestern Naturalist 38: 146-149. 
9. Feliu, C., Spakulova, M., Casanova, J. C., Renaud F., Morand, S., Hugot, J. P., Santalla, F. and Durand, P. 2000. J. Parasitol. 86: $442-449$.

10. Genov, T. 1984. Helminths of insectivorous mammals and rodents in Bulgaria. Publication House of the Bulgarian Academy of Sciences, Sofia, Bulgaria.

11. Ibrahim, M. A., Ogunsusi, R. A., Nwude, N. and Aliu, Y. 1984. Rev. Elevage Med. Vet. Pays Trop. 37: 304-307.

12. Ihama, Y., Sato, H., Makino, Y. and Kamiya, H. 2000. Parasitol. Int. 48: 303-306.

13. Ishimoto, Y. 1974. Jpn. J. Vet. Res. 22: 1-12.

14. Kamiya, M., Yabe, T. and Nakamura, Y. 1971. Jpn. J. Parasitol. 20: 490-494 (in Japanese with English summary).

15. Maravec, F. 1982. Folia Parasitol. 29: 119-132.

16. Saito-Ito, A., Tsuji, M., Wei, Q., He, S., Matsui, T., Kohsaki, M., Arai, S., Kamiyama, T., Hioki, K. and Ishihara, C. 2000. J. Clin. Microbiol. 38: 4511-4516.

17. Shiota, T., Kurimoto, H., Haguma, N. and Yoshida, Y. 1983.
Jpn. J. Parasitol. 32: 165-175 (in Japanese with English summary).

18. Tanaka, I. 1982. pp. 1-17. In: Pest Control Series 1 Rats and Mice and Their Control, Japan Environmental Sanitation Center, Tokyo (in Japanese).

19. Thompson, R. C. A., Reynoldson, J. A. and Mendis, A. H. W. 1993. Adv. Parasitol. 32: 71-160.

20. Uchida, A., Arakawa, O., Murata, Y. and Udagawa, T. 1984. Jpn. J. Parasitol. 33: 317-321 (in Japanese with English summary).

21. Yagi, K. and Kamiya, M. 1981. Jpn. J. Vet. Res. 29: 62-66.

22. Yagi, K., Takahashi, K., Hattori, K. and Ishige, M. 1986. Rep. Hokkaido Institute Pub. Hlth. 36: 30-42 (in Japanese).

23. Yamaguti, S. 1961. Systema Helminthum, vol. III. The Nematodes of Vertebrates. Parts I and II. Interscience Publishers, New York.

24. Yoshida, Y. 1991. pp. 186-187. In: Illustralted Human Parasitology, Nanzando Co., Tokyo (in Japanese). 